\title{
COMPARATIVE STUDY BETWEEN ANISE SEEDS AND MINT LEAVES (CHEMICAL COMPOSITION, PHENOLIC COMPOUNDS AND FLAVONOIDS)
}

\author{
A.A.E. Sakr(1), Kh. M. Taha(1), M. M. Abozid(1) and H. E.Z. El-saed(2) \\ (1) Biochemistry department, Faculty of Agriculture, Menoufia University \\ (2) Mashtoul Elsouk Hospital
}

Received: May. 19, 2019

Accepted: May 26, 2019

\begin{abstract}
The objective of research was to study the chemical composition , phenolic compounds and flavonoids of powder from anise seeds and mint leaves. Anise seeds contains: total carbohydrates $51.4 \%$, crude protein $18.1 \%$, total lipids $13.7 \%$ and total ash $14.9 \%$ in dry sample. While mint leaves contains contains total carbohydrates $55.7 \%$, crude protein $19.8 \%$, total lipids $4.9 \%$, and total ash $18.6 \%$ in dry sample. Total phenolic in anise seeds were 216.6-237.8 $\mathrm{mg} / 100 \mathrm{~g}$ in aqueous and ethanolic extracts, respectively and total flavonoids were 148.1-156.4 $\mathrm{mg} / 100 \mathrm{~g}$ in aqueous and ethanolic extracts, respectively comparing with $234.3-278.9 \mathrm{mg} / 100 \mathrm{~g}$ in aqueous and ethanolic extracts, respectively and 157.5-186.3 $\mathrm{mg} / 100 \mathrm{~g}$ in aqueous and ethanolic extracts, respectively of total phenolic compounds and flavonoids in mint leaves. HPLC results showed that anise seeds were found to contain 19 of phenolic compounds, amoung them catechein, cinnamic, ellagic, gallic, chlorogenic, ferulic and catechol were the major active in anise seeds, while mint leaves contained rosmaric, cinnamic, gallic, ferulic, and savianolic as the major of phenolic compounds. In conclusion the obtained results found that, anise seeds and mint leaves extracts were rich in secondary metabolites (phenolic compounds and flavonoids) with high nutritional and health values.
\end{abstract}

Key words: Anise seeds - Mint leaves - Total phenolics - Total flavonoids.

\section{INTRODUCTION}

Anise (Pimpinella anisum, L.), is an annual important spice and medicinal plant belonging to the family of Apiaceae, and native to Mediterranean region. Today, anise seeds are an important natural raw material which is used for pharmaceutics, perfumery, food and cosmetic industries. Recently, this spice plant has drawn more consideration of consumers due to the antimicrobial, antifungal, insecticidal, and anti oxidtaive effect of this herb on human health The genus Pimpinella, L. consist 150 species spread in Eurasia and Africa. (Gulcin et al., 2003). Anise seeds contain $1.5-5 \%$ essential oil and used as flavouring, digestive, carminative, and relief of gastrointestinal spasms. Consumption of anise seed in lactating women increases milk and also reliefs their infants from gastrointestinal problems, in the food industry, anise is used as flavoring and aromatic agent for fish products, ice cream, sweets, and gums (Said et al., 1996).

Mint plants are perennial, fast growing and generally tolar at wide range of agroclimatic conditions with the distribution across Europe, Africa, Asia, Australia and North America (Zhang 2002). Mint plants are herbaceous and perennial aromatic herbs that are cultivated for health care and culinary purposes. The taxonomy of genus Mentha is complicated and within the genus, more than $\mathbf{3 0 0 0}$ names have been published from species to which is the starting date of modern nomenclature, presently, only the names of about 1800 have been adequately studied ( Sharma et al., 2007 ). 
The pharmacological effects of mint (mentha piperita) are chiefly bound to the presence of two main compound groups: phenolic and essential oil compounds. The main phenolics in reported mint plants include derivatives of caffeic acid and glycosidic forms of the flavonoids luteolin, apigenin, eriodictyol and naringenin (Mckay and Blumberg 2006). The aims of the present study were to determine the chemical composition, total pheolic compounds and total flavonoids of anise seeds and mint leaves extracts, also, fractionation and determination of phenolic compounds in this two plants by using HPLC.

\section{MATERIALS AND METHODS \\ 1- Plant collection and Identification.}

Anise seeds and mint leaves were collected from El kanater Elkhiriah, Qulubia Governates, Egypt in January 2016. The leaves and seeds of plants were identified by botanical members of the Department of Botany, Faculty of Agriculture, Menoufia University. The leaves and seeds were allowed to dry in a shady and well-aired place, then dried at $50{ }^{\circ} \mathrm{C}$ and grounded into a powder state using commercial blender and finally used for analysis.

\section{2- Determination of chemical composition.}

\section{2-1: Determination of Ash:}

Ash content was determined by ashing at $550^{\circ} \mathrm{C}$ for 6 hours according to (AOAC, 2000).

\section{2-2: Extraction and determination of crude lipid:}

A known weight of the samples (10gm) was extracted with n-hexane 6 hours in Soxhlet apparatus. The solvent was evaporated and the residue was dried to constant weight and the percentage of total lipid was calculated, according to (AOAC, 2000).
2-3: Determination of Crude proteins:

Total nitrogen was determined (dry basis) according to the modified microKjeldahl method as described by AOAC, (2000). The crude protein contents were calculated using the conversion factor 6.25 .

Calculation Protein \% = TN (Total Nitrogen) X 6.25.

2-4: Determination of total carbohydrate:

A known weight $(0.2 \mathrm{gm}$.) of dried sample was completely hydrolyzed for 6 hours with $\mathrm{HCl}(1 \mathrm{~N})$ on boiling water bath under reflux condenser. The solution was then filtered and the filtrate was clarified by the leading and deleading method using lead acetate solution $(137 \mathrm{gm} / \mathrm{L})$ and excess of lead salts was precipitated using N/3 disodium hydrogen phosphate solution. The extract was transferred into a measuring flask $(50 \mathrm{ml}$.). The combind filtrate was completed to the mark with distilled water.

The sugars were determined according to the method of Dubois et al, (1956) as follows:-

An aliquot of $1 \mathrm{ml}$. of the sugars solution was quantitatively transferred into a test tube and treated with $1 \mathrm{ml} .5 \%$ aqueous phenol solution followed by 5 $\mathrm{ml}$. of concentrated sulphuric acid added by a fast delivery pipette. The blank experiment was carried out using $1 \mathrm{ml}$. of distilled water instead of the sugar solution. The absorbance of yelloworange color was measured in spectrophotometer at wavelength 490 nm. A standard curve was prepared using known concentration of glucose. The established curve was used to convert the colorimeter absorbance into milligrams of glucose. 


\section{3: Determination of total phenolic compounds contents:-}

The amount of total phenolics in extracts was determined with the FolinCiocalteu reagent. Gallic acid was used as a standard and the total phenolics were expressed as $\mathrm{mg} / \mathrm{g}$ gallic acid equivalents (GAE). $10 \mathrm{~mL}$ of samples were prepared in methanol. $0.5 \mathrm{~mL}$ of each sample and standards were introduced into test tubes and mixed with $2.5 \mathrm{~mL}$ of a 10 fold dilute Folin-Ciocalteu reagent and $2 \mathrm{~mL}$ of $7.5 \%$ sodium carbonate. The tubes were covered with parafilm and allowed to stand for $\mathbf{3 0}$ minutes at room temperature before and the absorbance was at read at $760 \mathrm{~nm}$ spectrometrically (Kim et al., 2003).

\section{4: Determination of total flavonoids contents:-}

The total flavonoids contents were determined using the method reported by Dewanto et al., (2002). Briefly, an aliquot $(250 \mu \mathrm{L})$ of each extract or a standard solution was mixed with $1.25 \mathrm{~mL}$ of deionised water followed by $75 \mu \mathrm{L}$ of a $5 \% \mathrm{NaNO}_{2}$ solution. After $6 \mathrm{~min}, 150 \mu \mathrm{L}$ of a $10 \% \mathrm{AlCl}_{3} \cdot 6 \mathrm{H}_{2} \mathrm{O}$ solution was added to each mixture. After $5 \mathrm{~min}, 0.5 \mathrm{~mL}$ of 1 $\mathrm{M} \mathrm{NaOH}$ was added, and the total volume was adjusted to $3.0 \mathrm{~mL}$ with deionised water. Catechin was used as a standard. The absorbance at $510 \mathrm{~nm}$, which was corrected using a blank, was then determined and the results were expressed as $\mathrm{mg}$ of catechin equivalents (CE)/100 g flavonoids weigh.

\section{5: Quantitative Determination of Phenolics by HPLC.}

Phenolic compounds were determination by HPLC according to the method of Goupy et al., (1999) as follow: $5 \mathrm{~g}$ of samples were mixed with methanol and centrifuged at $10000 \mathrm{rpm}$ for $10 \mathrm{~min}$ and supernatant was filtered through a
$0.2 \mu \mathrm{m}$ Millipore membrane filter then 1-3 $\mathrm{ml}$ was collected in a vial for injection in to HPLC Hewilet Packared (series 1050) equipped with auto sampling injection, solvent degasser, ultravilot (UV) detector set at $280 \mathrm{~nm}$ and quaternary HP pump (series 1050). Hewlett Packard using a column Alltima C18, $5 \mathrm{~mm}(150 \mathrm{~mm} x$ $4.6 \mathrm{~mm}$ All tech) the column temperature was maintained at $35{ }^{\circ} \mathrm{C}$. Gradient separation was carried out with methanol and acetonitrile as a mobile phase at flow rate of $1 \mathrm{ml} / \mathrm{min}$. Phenolic acid standard from sigma Co. were dissolved in a mobile phase and injected into HPLC. Retention time and peak area were used to calculation of phenolic compounds concentration by the data of Hewllet Packared software.

\section{RESULTS AND DISCUSSION}

\section{1: Chemical compositioncontents of anise seeds and mint leaves :}

The obtained results in Table (1) indicated that anise seeds contains total ash $14.9 \%$, total lipids $13.7 \%$, crude protein $18.1 \%$, and total carbohydrates $51.4 \%$,while mint leaves contains total ash $18.6 \%$, total lipids $4.9 \%$, crude protein $19.8 \%$, and total carbohydrates $55.7 \%$.

These results are in line with those of Madhu et al., (2014) who found that chemical composition of anise seeds was : total lipids $14.2 \%$, crude protein $17.6 \%$, and total carbohydrates $50.9 \%$, while James and Emmanuel (2011) reported that chemical composition of mint leaves was : total lipids $5.3 \%$, crude protein $18.3 \%$, and total carbohydrates $56 \%$. So the obtained results can suggested that there are no big different in main chemical composition (total carohydrates, total protein, total lipids and ash ratios) for different plants from the same spicies. 
A.A.E. Sakr, et al.,

Table (1): Chemical composition of anise seeds and mint leaves.

\begin{tabular}{|c||c|c|}
\hline Chemical composition & $\begin{array}{c}\text { Anise seeds } \\
(\mathrm{g} / 100 \mathrm{~g}) \mathrm{D} . w\end{array}$ & $\begin{array}{c}\text { Mint leaves } \\
(\mathrm{g} / 100 \mathrm{~g}) \mathrm{D} . w\end{array}$ \\
\hline \hline Ash & 14.9 & 18.6 \\
\hline \hline Total lipids & 13.7 & 4.9 \\
\hline \hline Crude protein & 18.1 & 19.8 \\
\hline \hline Total carbohydrates & 51.4 & 55.7 \\
\hline
\end{tabular}

2. Total phenolic compounds, total flavonoids and antioxidant activity of anise seeds and mint leaves extracts.

Data in Table (2) showed that total phenolics and total flavonoids contents in mint leaves extracts are higher than those found in anise seeds extracts. Total phenolics in anise seeds extracts has been ranged from 216.6 to 237.8 $\mathrm{mg} / \mathrm{g}$, while total flavonoids has been ranged from 148.1 to $156.4 \mathrm{mg} / \mathrm{g}$, comparing with 234.3 to $278.9 \mathrm{mg} / \mathrm{g}$ and 157.5 to $186.3 \mathrm{mg} / \mathrm{g}$ of total phenolic and total flavonoids, respectively in mint leaves extracts.

These data are in line with those of Bagdassarian et al., (2013) who found that anise seeds extracts contain a high amount of total phenolic and total flavonoids compounds.

These results agree also with Atanassova et al., (2011) who found that mint leaves extracts rich in total phenolic and total flavonoids compounds.

A high content of penolics and flavonoids in both anise seeds and mint leaves, both plants are an important natural raw material which is used for pharmaceuticts, and food issues. Recently, these plants have drawn more consideration of consumers due to the antimicrobial and antioxidant effect of it on human health.

3. Quantitative analysis of phenolic compounds of anise seeds and mint leaves.

Phenolic compounds in anise seeds and mint leaves were analyzed by High Performance Liquid Chromatography (HPLC), and concentration of all tested phenolic compounds are given in Table (3). Analysis of anise seeds showed that catechein reached $71.68 \mathrm{mg} / 100 \mathrm{~g}$, followed by gallic acid $(60.75 \mathrm{mg} / 100 \mathrm{~g})$, caffeic acid (44.52 $\mathrm{mg} / 100 \mathrm{~g})$ and cinnamic acid $(16.1 \mathrm{mg} / 100 \mathrm{~g})$ dry weight, while mint leaves contains rosmarinic acidas the main phenolic compound (219.6 $\mathrm{mg} / 100 \mathrm{~g})$, followed by salvianolic acid (18.3 mg/100g).

Results of phenolic compounds analysis are nearly similar to those reported by Slinkard and Singleton (1997) who studied the main phenolic compounds in anise seeds and found that anise seeds contains catechein $\mathbf{7 5 . 6}$ $\mathrm{mg} / 100 \mathrm{~g})$ followed by gallic acid $(60.89$ $\mathrm{mg} / 100 \mathrm{~g}$ ), followed by caffeic acid (45.4 $\mathrm{mg} / 100 \mathrm{~g})$ and cinnamic acid (27.3 $\mathrm{mg} / 100 \mathrm{~g}$ ). These results agree also with Unger and Frank (2004) who found that the main phenolic compounds in mint leaves is rosmaric acid $(225.1 \mathrm{mg} / 100 \mathrm{~g})$ and salianolic acid (19.8 $\mathrm{mg} / 100 \mathrm{~g})$. 
Table (2): Total phenolic compounds and total flavonoids content of anise seeds and mint leaves extracts.

\begin{tabular}{||l||c||c||c||c||}
\hline \multirow{2}{*}{ Chemical composition } & \multicolumn{2}{c|}{ Anise seeds } & \multicolumn{2}{c||}{ Mint leaves } \\
\cline { 2 - 5 } & $\begin{array}{c}\text { Total } \\
\text { phenolics } \\
\text { mg/100g }\end{array}$ & $\begin{array}{c}\text { Total } \\
\text { flavonoids } \\
\text { mg/100g }\end{array}$ & $\begin{array}{c}\text { Total } \\
\text { phenolics } \\
\text { mg/100g }\end{array}$ & $\begin{array}{c}\text { Total } \\
\text { flavonoids } \\
\text { mg/100g }\end{array}$ \\
\hline \hline Ethanolic extract & 237.8 & 156.4 & 278.9 & 186.3 \\
\hline \hline Water extract & 216.6 & 148.1 & 234.3 & 157.5 \\
\hline
\end{tabular}

Table (3): Phenolic compounds in anise seeds and mint leaves.

\begin{tabular}{|c|c|c|}
\hline \multirow{2}{*}{ Phenolic compounds } & \multicolumn{2}{|c|}{ Content (mg/100g )D.w } \\
\hline & Anise seeds & Mint leaves \\
\hline Catechein & 71.68 & 5.19 \\
\hline Epicatechein & 11.38 & 2.13 \\
\hline Caffeine & 3.58 & 3.91 \\
\hline Caffeic acid & 44.52 & 7.95 \\
\hline Ellagic acid & 10.64 & 4.48 \\
\hline Cinnamic acid & 24.26 & 9.81 \\
\hline Rosmarinic acid & 4.88 & 219.6 \\
\hline Salycilic acid & 7.07 & 3.45 \\
\hline Pyrogallol & 6.29 & 5.58 \\
\hline P-Coumaric acid & 5.01 & 3.32 \\
\hline Salvianolic acid & 1.84 & 18.3 \\
\hline Protocatchuic & 1.98 & 1.1 \\
\hline Chlorogenic acid & 11.85 & 6.14 \\
\hline Coumarin & 1.03 & 4.07 \\
\hline Catechol & 21.91 & 2.2 \\
\hline Alpha-Coumaric & 18.74 & 5.16 \\
\hline Ferulic acid & 36.63 & 11.55 \\
\hline Gallic acid & 60.75 & 12.43 \\
\hline 3,4,5-methoxy-cinnamic & 0.75 & 0.43 \\
\hline
\end{tabular}


The obtained data indicated that, catechein was the major flavonoids in anise seeds while, rosmarinic acid recorded the hight amount in mint leaves. Both of these flavonoids are known by its hight value as antioxidant and antimicrobial agents, so we can connected between types of flavonoids in plants and role of it as antimicrobial and antioxidant uses.

\section{Conclusion.}

In conclusion, the chemical compostion of anise seeds and mint leaves is very similar in terms of the essential components (total ash, total carbohydrate, and crude protein), except for the hight total lipids content of the anise seeds, while mint leaves contain higher levels of phenolic compounds and total flavonoids. The HPLC analysis showed a difference in the types of phenolics in two plants. Anise seeds were characterized by high catechins, while mint leaves were characterized by high content of rosmarinic acid, both plants were considered a good sources of important natural products in human nutrition.

\section{REFERENCES}

A.O.A.C. Association of Official Analytical Chemists (2000). Official Methods of Analysis, 15th Edn. Washington, D.C.

Atanassova, M., S. Georgieva and K. Ivancheva (2011). Total phenolic and total flavonoid contents, antioxidant capacity and biological contaminants in medicinal herbs. J. Univ. Chem. Technol. Metall., 46:81-88.

Bagdassarian, C.L.V., S.K. Bagdassarian and S.M. Atanassova (2013). Phenolic Compounds and Antioxidant Capacity in Bulgarian Plans (dry seeds): International Journal, 1 (9):186-197.
Dewanto, V., X. Wu, K.K. Adom and R.H. Liu (2002). Thermal processing enhances the nutritional value of tomatoes by increasing total antioxidant activity. J Agric Food Chem., 50: 3010-3014.

Dubois, M., F. Smith, K.A. Gilles, J.K. Hammilton and P.A. Rebers (1956). Colorimetric method for determination of sugars and related substance. Anal.Chem., 28 (3): 350 - 356.

Gulcin, I., M. Oktay, E. Kirecci and O.I. Kufrevioglu (2003). Screening of antioxidant and antimicrobial activities of anise (Pimpinella anisum, L.) seed extracts. Food Chem; 83:371382.

Goupy, P., M. Hugues, P. Biovin and M.J. Amiot (1999). Antioxidant composition and activity of barley (Hordeum vuigare) and malt extracts and of isolated phenolic compounds. J. Sci. Food Agric., 79: 1625 -1634.

James, O. and U.C. Emmanuel (2011). "Comparative studies on chemical composition and Mineral of some selected Nigerian Vegetables", African Journal of Food Science, 5(1) : 22-25.

Kim, D.O., S.W. Jeong and C.Y. Lee (2003). Antioxidant capacity of phenolic phytochemicals from various cultivars of plums. Food Chem., 81:321-326.

Madhu, C.S., H.M. Manukumar, K.R. Thribhuvan and R. P. Bhimangouda (2014). Phytochemical, nutritional and mineral constituents of anise (Pimpinella anisum, L.) seeds. World Journal of Pharmaceutical Research, 3(2):2888-2896.

McKay, D.L. and J.B. Blumberg (2006). A review of the bioactivity and potential health benefits of peppermint tea (Mentha piperita, L.). Phytother Res., 20(8):619-633. 
Said, H.M., A. Saeed, L.A. D'Silva, H.N. Zubairy and Z. Bano (1996). Medicinal herbal: a textbook for medical students and doctors. Hamdard Foundation Pakistan, Pakistan, pp 182.

Sharma, A., M.K. Sharma and M. Kumar (2007). Protective effect of Mentha piperita against arsenicinduced toxicity in liver of Swiss albino mice. Basic Clin.Pharmacol.Toxicol., 100 (4):249-257.

Slinkard, K. and V. L. Singleton (1997). Total phenol analysis: Automation and comparison with manual methods.
American J. of Enology and Viticulture, 28:49-55.

Unger, M. and A. Frank (2004). Simultaneous determination of the inhibitory potency of herbal extracts on the activity of six major cytochrome P450 enzymes using liquid chromatography/mass spectrometry and automated online extraction. Rapid Commun Mass Spectrorn, 18: 2273-81.

Zhang, X. (2002). WHO Traditional Medicine Strategy 2002-2005; World Health Organization: Geneva, Switzerland. 
دراسة مقارنة بين بذور اليانسون وأولق النعناع ( التركيب الكيميائي، (المركبات الفينولية والفلافونات)

عبد العزيز علي إبراهيم صقر (')، خالد مأمون طه(")، مدحت مصطفي أبوزيد (')،

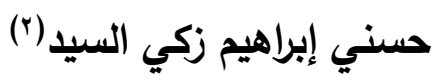

(1) قسم الكيمياء الحيوية - كلية الزراعة - جامعة المنوفية.

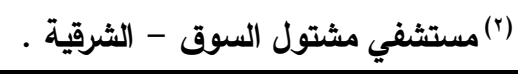
الملخص العربي تهاف هذه الدراسة إلي التعرف علي التركيب الكيميائي وكذلك المركبات الفينولية والفلافونات في كلا من بذور

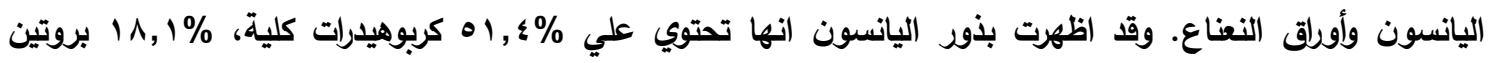

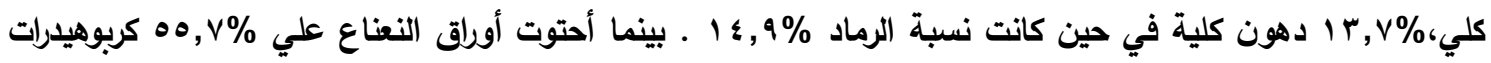

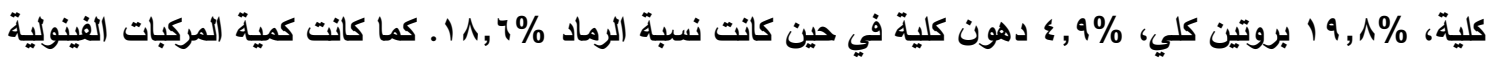

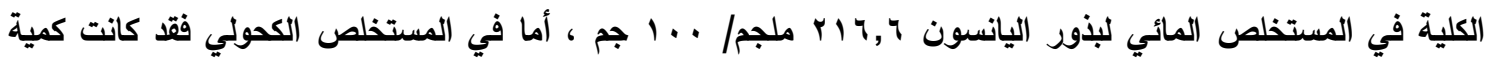

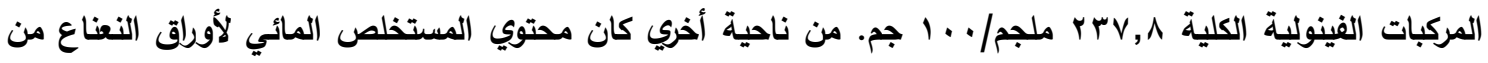

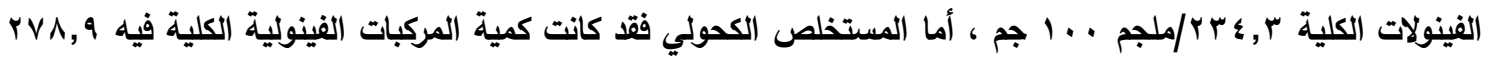

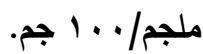

وقد أظهرت الفلافونات الكلية نفس السلوك فقد كان محتوي المستخلص المائي لبذور اليانسون من الفلافونات الكلية

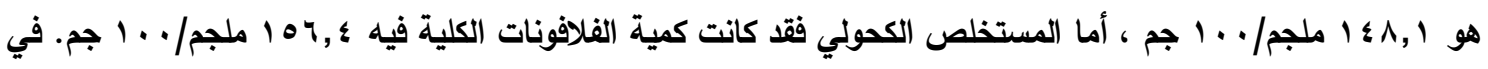

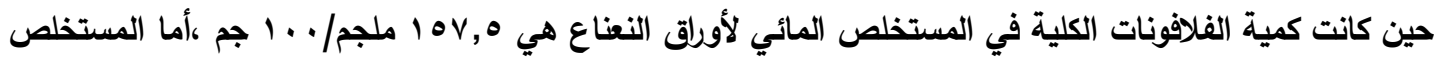

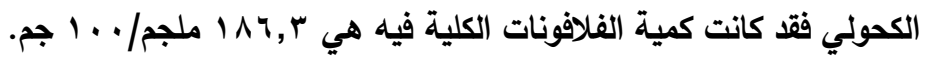

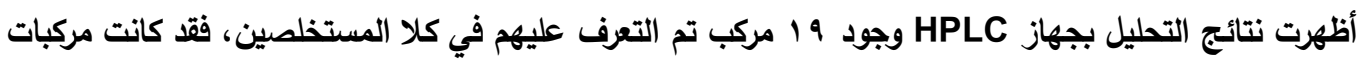

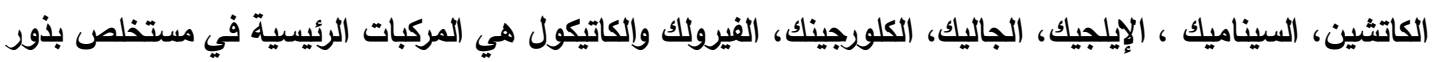

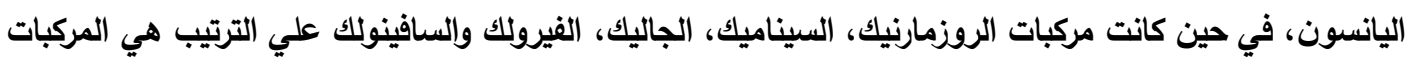
الرئيسية في أوراق النعناع.

ويمكن تلخيص ماسبق بالقول بأن كلا من بذور اليانسون اولق النعناع غنيان بالمركبات الثانوية النباتية (الفينولات وإلفلافونات) مما يعطيها قيمة غذائية وصحية عالية. الكلمات الدالة : بذور اليانسون - أوراق النعناع - الفينولات الكلية - الفلافونات الكلية.

كلية الأقتصاد المنزلى - جامعة المنوفية أسماء السادة المحكمون: 
Comparative study between anise seeds and mint leaves (Chemical .............. 